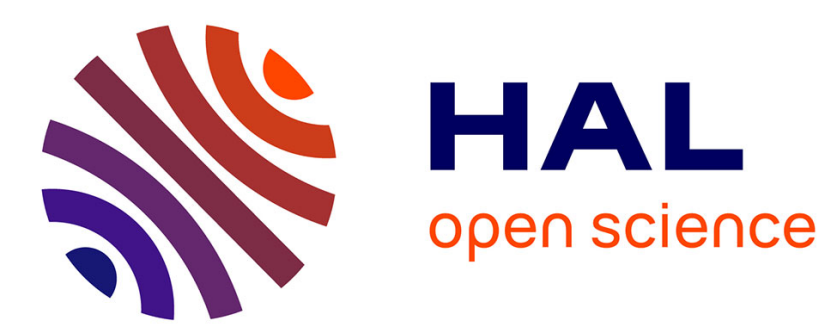

\title{
Identification and genetic diversity of Bacillus cereus strains isolated from a pasteurized milk processing line in Algeria
}

\author{
Fadila Malek, B. Boudjemaa, A. Aouar-Métri, M. Kihal
}

\section{- To cite this version:}

Fadila Malek, B. Boudjemaa, A. Aouar-Métri, M. Kihal. Identification and genetic diversity of Bacillus cereus strains isolated from a pasteurized milk processing line in Algeria. Dairy Science \& Technology, 2013, 93 (1), pp.73-82. 10.1007/s13594-012-0093-2 . hal-01201412

HAL Id: hal-01201412

https://hal.science/hal-01201412

Submitted on 17 Sep 2015

HAL is a multi-disciplinary open access archive for the deposit and dissemination of scientific research documents, whether they are published or not. The documents may come from teaching and research institutions in France or abroad, or from public or private research centers.
L'archive ouverte pluridisciplinaire HAL, est destinée au dépôt et à la diffusion de documents scientifiques de niveau recherche, publiés ou non, émanant des établissements d'enseignement et de recherche français ou étrangers, des laboratoires publics ou privés. 


\title{
Identification and genetic diversity of Bacillus cereus strains isolated from a pasteurized milk processing line in Algeria
}

\author{
F. Malek • B. Moussa Boudjemaa • A. Aouar-Métri • \\ M. Kihal
}

Received: 1 May 2012 /Revised: 4 September 2012 / Accepted: 6 September 2012 / Published online: 18 October 2012

(C) INRA and Springer-Verlag France 2012

\begin{abstract}
Bacillus cereus is a food pathogen of major concern to the dairy industry. Strains of B. cereus were isolated in 2006 and 2010 from a pasteurized milk processing line in a dairy plant in Algeria. Pasteurized milk is obtained from reconstituted and processed milk powder. This study was designed to discriminate between the isolated B. cereus strains and to predict their food poisoning potential. Strains were fingerprinted by M13-PCR, and identified at the phylogenetic group level by amplified panC gene sequence analysis. They were clustered into three distinct M13-PCR groups: one major group which included 17 strains and two minor groups which contained two and one strains, respectively. Strains originating from both the process equipment and milk powder were from the major group indicating that milk powder was the main source of initial contamination. Strains from the major and second group were affiliated to the mesophilic phylogenetic group III while the unique strain of the third group was classified into the mesophilic phylogenetic group IV. The data presented in this study showed a very low genetic diversity among B. cereus strains identified in milk powder and secondly by milk processing systems, as well as persistence in the dairy environment of specific $B$. cereus genotypes, across 4 years. M13-PCR typing and phylogenetic affiliation were useful for characterizing $B$. cereus dairy isolates,
\end{abstract}

F. Malek • B. M. Boudjemaa

Laboratory of Applied Microbiology (LAMAABE), University of Tlemcen, Tlemcen 13000, Algeria

A. Aouar-Métri

Department of Ecology and Environment, University of Tlemcen, Tlemcen 13000, Algeria

M. Kihal

Laboratory of Applied Microbiology, University of Senia, Oran 31000, Algeria

F. Malek $(\bowtie)$

Department of Biology, University of Tlemcen, Tlemcen 13000, Algeria

e-mail:malekfad@yahoo.fr 
permitting their differentiation within the B. cereus group, and showing homogeneous contamination throughout the pasteurized milk processing line. The recurrent genotypes which belong to the potentially toxigenic group III $B$. cereus could threaten pasteurized milk safety.

\section{阿尔及利亚巴氏杀菌乳加工生产线上分离的蜡状芽狍杆菌的分离鉴定与遗传多样性的研究}

摘要：蜡状芽孢杆菌是乳品行业中比较受关注的一种食品级病原菌。在2006年和2010年从 阿尔及利亚乳品厂巴氏杀菌乳加工生产线上分离出蜡状芽孢杆菌。该工厂巴氏杀菌乳以复 原乳和奶粉为原料。本研究目的是分离鉴别蜡状芽狍杆菌并预测他们对食物的潜在毒性。 分离的菌株通过M13引物PCR指纹法分析, 菌株的系统发育组别水平通过panC 基因序列分析法 来鉴定。这些菌株被分成三个不同的M13-PCR菌群：一个是具有17 菌株的大菌群和两个分别 仅含有 2 株和 1 株的小菌群。这些菌株既来自加工设备, 也来自奶粉, 其中奶粉是菌株的主要 来源物, 奶粉是主要的污染源。来自主要菌群的菌株和次级菌群中的 1 株菌株属于嗜温菌种 属III, 然而第三组菌群中仅有的 1 株菌株属于嗜温菌种属 IV。本研究的数据表明从奶粉和奶 加工体系中分离的蜡状芽孢杆菌有较低的遗传多样性, 在四年生产过程中特殊的蜡状基因型 菌株一直存在于乳品环境中。M13-PCR 分类技术和菌种隶属对蜡状芽狍杆菌的定性很有用, 允许蜡状芽孢杆菌菌属内部存在差异, 同时表明了在整个巴氏杀菌乳生产线上存在相似的污 染。重复出现的基因型菌株属于潜在的产毒蜡状芽孢杆菌属III, 能够严重威胁到巴氏杀菌 乳的安全。

Keywords Bacillus cereus group · M13-PCR typing · Phylogenetic groups · Dairy equipment $\cdot$ Milk powder $\cdot$ Pasteurized milk

关键词 蜡状芽狍杆菌属· M13-PCR 分类·系统发育组 · 乳品设备 · 奶粉 · 巴氏杀菌乳

\section{Introduction}

Bacillus cereus sensu lato comprises closely related species that are of significant economic and clinical importance. With respect to human health, these bacteria can cause a wide range of diseases, including food poisoning, systemic infections, and highly lethal forms of anthrax (Didelot et al. 2009). Bacillus cereus sensu stricto is a frequent contaminant of food processing plants and is associated with food poisoning and spoilage. Hence, identification of $B$. cereus sensu lato is an important concern for the food industry.

Recent changes in the classification of the B. cereus group notably definition of phylogenetic groups (Guinebretière et al. 2008), modified to a large extent, identification within this group of bacteria. Indeed, the B. cereus group is actually composed by species that are not considered as separate genomic species but are distributed between seven phylogenetic groups (Guinebretière et al. 2008, 2010). These phylogenetic groups can be recovered in the Tourasse-helgason MLST database (http://mlstoslo.uio.no/). In addition to the six known species (B. cereus sensu stricto, Bacillus anthracis, Bacillus thuringiensis, Bacillus mycoides, Bacillus pseudomycoides, and Bacillus weihenstephansis), a potentially novel species, Bacillus cytotoxicus has been placed in the phylogenetic group VII, and characterized by its high toxicity, its particular thermotolerance (growth at $50{ }^{\circ} \mathrm{C}$ ), and its relatively rare occurrence. 
Strains of the B. cereus group are also recognized to be highly, weakly, or nonpathogenic, depending on their potential to produce or not produce toxins (Svensson et al. 2007; Guinebretière et al. 2008, 2010; De Jonghe et al. 2010). Moreover, the ability of strains to cause food poisoning was recently reported to vary according to their phylogenetic affiliation (groups I to VII) rather than species affiliation (Guinebretière et al. 2010). Consequently, in the food industry identification of bacterial strains at the phylogenetic group level is more pertinent than at species level to assess the food safety of the products.

In the dairy industry, B. cereus group spp., especially psychrothrophic strains, are recognized to limit the keeping quality of pasteurized milk (Svensson et al. 2004; Hanson et al. 2005; Barbano and Santos 2006; Aires et al. 2009). Contamination of pasteurized milk has been mainly traced to raw milk (Lin et al. 1998; Huck et al. 2007; Banykó and Vyletelová 2009) and/or equipment surfaces. The role of processing equipment as a reservoir for $B$. cereus milk recontamination is well documented (Te Giffel et al. 1997; Svensson et al. 1999, 2000, 2004; Schlegelova et al. 2010) notably post-pasteurization contamination (Eneroth et al. 2001; Sharma and Anand 2002; Salustiano et al. 2009). Currently, the persistence of this pathogen in various environments has been attributed to the formation of spores as well as biofilms. Thus it is important to accurately identify the sources of contamination and trace the spread of $B$. cereus in dairy plants. This may lead to a reduction in the level and incidence of $B$. cereus in pasteurized milk and improve the quality and shelf-life of the product.

Previous studies have reported a high incidence of $B$. cereus group strains in Algerian raw and pasteurized milk samples (Moussa Boudjemaa et al. 2004). High counts of these bacteria were also found on the process equipment surfaces of five dairy plants, which were suspected to be an important source of potential pasteurized milk recontamination (unpublished data). However, these strains have not been characterized further.

Rapid molecular typing methods such as sequence-based PCR or RAPD are widely used for typing B. cereus isolates (Guinebretière and Nguyen-The 2003; Svensson et al. 2004; Ehling-Schulz et al. 2005; Svensson et al. 2006; Thorensen et al. 2010). These genotypic methods are recognized to be good tools for tracing contaminations routes of $B$. cereus in pasteurized milk and have successfully been used for this purpose (Te Giffel et al. 1997; Svensson et al. 1999, 2000; Eneroth et al. 2001). Likewise the panC gene is a housekeeping gene described to provide a better opportunity to distinguish very closely related ecological populations, than ribosomal sequence data, and to rapidly assign bacterial isolates to groups I to VII of the phylogenetic classification (Guinebretière et al. 2008, 2010).

In the present study, isolates from one of these dairy plants, which had been investigated for several years for the presence of strains of $B$. cereus, were further characterized using the molecular typing M13-sequence-based polymerase chain reaction (M13-PCR). They were also assigned to phylogenetic groups (I to VII) based on panC sequence analysis. The main objectives were (1) to give more comprehensive data concerning the main sources of contamination for pasteurized milk, (2) to predict, in a first rapid step, their food poisoning potential using, as suggested by Guinebretière et al. (2010), a more accurate identification of representative strains (affiliation to phylogenetic groups within the B. cereus group). 


\section{Materials and methods}

\subsection{The processing plant}

$B$. cereus isolates were collected in a dairy plant situated in northwest Algeria. Approximately 60,000 1 of milk are handled per day in the plant. As local milk production is insufficient, in the 1970s the Algerian authorities began to import milk powder from various foreign countries. The milk powder is reconstituted and processed to obtain recombined pasteurized milk (Fig. 1).

\subsection{Bacterial strains}

Fifty strains belonging to the $B$. cereus group were isolated from monthly samplings of a pasteurized milk processing line over 4 years (in 2006 and 2010), and also from milk powder samples. All isolates were Gram-positive rods, spore producers, catalase positive, motile, and produced typical reactions on MYEP agar and hemolysis in blood agar. From these 50 isolates, 20 strains were selected for a more accurate molecular typing, based on their origin and morphological aspect of colonies. This resulted in a set of 20 strains with distinct origins and isolation periods (Table 1).

\subsection{Molecular typing}

\subsubsection{M13-PCR}

DNA preparation was performed according to the protocol described by Guinebretière and Nguyen-The (2003). The 20 isolates were typed by M13-PCR, using

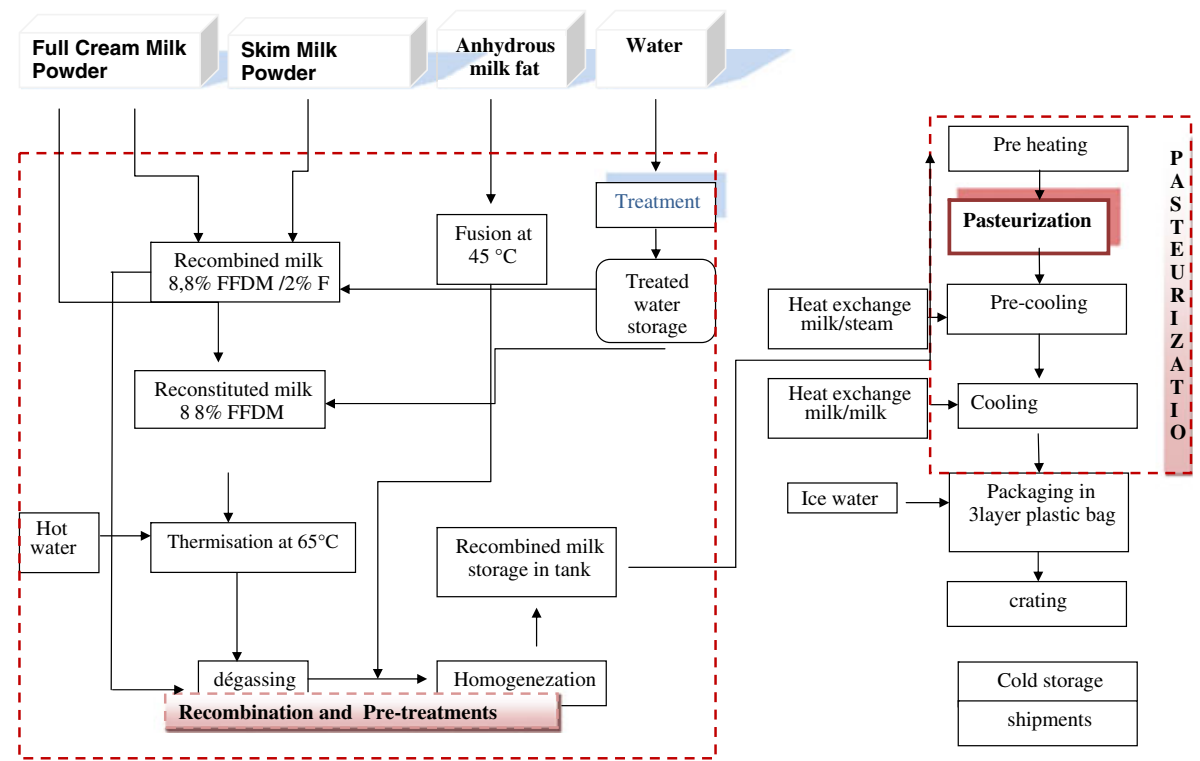

Fig. 1 Process flow diagram of recombined pasteurized milk at the dairy plant 
Table 1 Molecular typing (M13-PCR) and phylogenetic affiliation of $20 \mathrm{~B}$. cereus group strains isolated from different origins along the processing line

\begin{tabular}{|c|c|c|c|c|c|}
\hline Strain origin & Year & M13 genotype & Representative strains & \multicolumn{2}{|c|}{$\begin{array}{l}\text { Pan } C \text { gene sequence analysis } \\
\text { phylogenetic group - identity }(\%)^{\mathrm{a}}\end{array}$} \\
\hline \multicolumn{6}{|l|}{ Milk powder } \\
\hline $\mathrm{BC} 1$ & 2010 & A & & & \\
\hline $\mathrm{BC} 5$ & 2010 & A & & & \\
\hline BC9 & 2010 & A & & & \\
\hline $\mathrm{BC} 12$ & 2010 & A & & & \\
\hline $\mathrm{BC} 19$ & 2010 & A & BC19 & Group III & 99.72 \\
\hline \multicolumn{6}{|c|}{ Pre-pasteurization } \\
\hline \multicolumn{6}{|l|}{ Segments } \\
\hline $\mathrm{BC} 2$ & 2010 & A & $\mathrm{BC} 2$ & Group III & 99.72 \\
\hline BC6 & 2010 & A & & & \\
\hline $\mathrm{BC} 7$ & 2010 & A & & & \\
\hline $\mathrm{BC} 8$ & 2010 & A & & & \\
\hline BC13 & 2010 & A & & & \\
\hline BC18 & 2010 & A & & & \\
\hline $\mathrm{BC} 20$ & 2010 & A & & & \\
\hline BC10 & 2006 & A & & & \\
\hline $\mathrm{BC} 11$ & 2006 & A & & & \\
\hline $\mathrm{BC} 17$ & 2006 & A & & & \\
\hline \multicolumn{6}{|c|}{ Post-pasteurization } \\
\hline \multicolumn{6}{|l|}{ Segments } \\
\hline B15 & 2010 & A & $\mathrm{BC} 15$ & Group III & 99.72 \\
\hline B16 & 2010 & A & & & \\
\hline \multicolumn{6}{|c|}{ Pre-pasteurization } \\
\hline \multicolumn{6}{|l|}{ Segment } \\
\hline $\mathrm{BC} 3$ & 2010 & B & $\mathrm{BC} 3$ & Group III & 100 \\
\hline $\mathrm{BC} 4$ & 2006 & B & & & \\
\hline \multicolumn{6}{|c|}{ Pre-pasteurization } \\
\hline \multicolumn{6}{|l|}{ Segment } \\
\hline BC14 & 2010 & $\mathrm{C}$ & $\mathrm{BC} 14$ & Group IV & 100 \\
\hline
\end{tabular}

${ }^{a}$ According to phylogenetic groups defined in Guinebretière et al. (2008, 2010)

the PCR reaction and the thermal cycling previously described (Guinebretière and Nguyen-The 2003). PCR products from M13-PCR were separated on 1.5\% agarose gel, and the molecular weight DNA marker SmartLadder SL (Eurogentec) was used as a reference. Gels were stained with ethidium bromide and digitized using a gel imager (Bioblock, III-kirch, France).

\subsubsection{PanC gene sequence analysis}

The panC gene was sequenced for representative strains of the three M13-PCR groups. Polymerase chain reaction amplification, purification, and sequencing were 
carried out as previously described in Guinebretière et al. (2008). Affiliation to the phylogenetic groups using the resulting panC gene sequences was performed on the web site: http:/www.tools.symprevius.org/Bcereus/english.php

\section{Results}

\subsection{Clustering of isolates according to their M13-PCR patterns}

After gel electrophoresis of the M13-PCR products for each of the 20 analyzed strains, a relatively simple profile of DNA fragments was obtained (Fig. 2). Thus, all the isolates were easily classified into three M13 genotypes, a major one (A) and two minor (B and C). A very low level of genetic diversity was identified between these strains. Indeed, most of the strains were represented in the major M13 genotype A, despite their various origins (Table 1). Seventeen strains isolated from the processing equipment and milk powder were similar (genotype A), suggesting that the milk powder is the source of contamination of the milk processing system. In contrast, genotypes $\mathrm{B}$ and $\mathrm{C}$, represented respectively by strains $\mathrm{BC} 3 / \mathrm{BC} 4$, and $\mathrm{BC} 14$, could not be related to a specific source of contamination and were not recovered in the pasteurized milk (only genotype A was recovered in the postpasteurization segments).

Interestingly, strains originating from the 4-year-old culture collection were identical to recently isolated strains from the same processing line, suggesting the persistence of genotypes A and B. As the nearly unique source of contamination for the pasteurized milk, the milk powder seems to be a source of homogeneous contamination.

\subsection{Identification to phylogenetic groups}

Five strains representative of the M13 genotypess were identified by panC gene sequences analysis on the web site: https://tools.symprevius.org/Bcereus/english.php.

Fig. 2 M13-PCR patterns generated for B. cereus group strains. Lanes 1 to $7 \mathrm{M} 13-\mathrm{PCR}$ (genotype A): strains BC 19, 12, 13, 2, 5, 7, and 8. Lane $8 \mathrm{M} 13$-genotype C: strain BC 14. Lanes 9 and 10 M13-genotype B: strains BC 4 and BC 3. Lane $M$ DNA molecular mass marker (Ladder S L, Eurogentec)

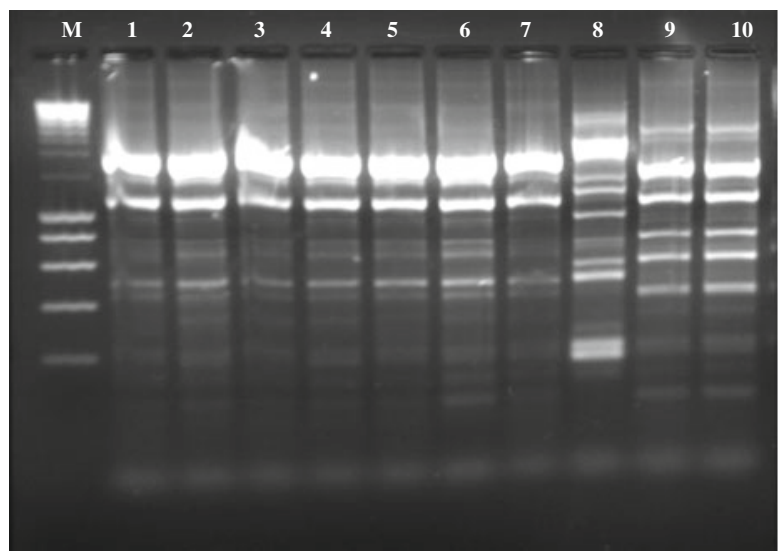


The $B$. cereus group identity of isolates was thus confirmed and their assignation to phylogenetic groups, according to the Guinebretière et al. (2008) classification, was achieved (Table 1).

Results showed that genotypes A and B (i.e., 19 out of 20 analyzed strains) were affiliated to the mesophilic phylogenetic group III, whereas the last one (genotype C) to the mesophilic phylogenetic group IV (Table 1). Genotypes A and B are from the same phylogenetic group (group III), indicating a higher genetic relatedness than with genotype $\mathrm{C}$. This finding corroborates the M13-PCR fingerprinting results. Therefore, the affiliation to phylogenetic groups III also indicates that these strains belong to one of the most cytotoxic groups (Guinebretière et al. 2010) comprising diarrheic as well as emetic strains, and that they probably represent a potential risk for consumers.

\section{Discussion}

Molecular methods used in this study allowed the genotyping and affiliation to phylogenetic groups of $20 \mathrm{~B}$. cereus strains isolated from an investigated dairy plant. All strains were successfully characterized by the M13-PCR method used and their plant distribution accurately elucidated.

The fingerprints generated by M13-PCR revealed a low genetic diversity among the isolates. The 17 undistinguishable strains (genotype A) were found at different sampling points of the pasteurized milk processing line (pre- and post-pasteurization segments) and milk powder. This contrasts with data from the literature where a greater diversity of RAPD patterns among B. cereus strains isolated from dairy plants was recorded (Svensson et al. 1999, 2000, 2004). As an illustration, Eneroth et al. (2001) found that several B. cereus RAPD types originated from one sample only. The low genetic diversity identified by our results should be, first, ascribed to the nature of the raw material, i.e., milk powder which initially may harbor only a few genotypes. Indeed dehydrated products are assumed not to have favorable conditions for a wide diversity (Guinebretière and Nguyen-The 2003). Secondly, the pressure exerted by food processing conditions in factories is assumed to select some genetic groups (Carlin et al. 2010). Accordingly, restrictive processes such as heat treatment, often at abusive temperatures, both during milk powder production and milk powder processing may result in reducing the diversity of the processing plant microflora. This is consistent with the concept of the in-house microflora (Bagge-Ravn et al. 2003), which may be partly a reflection of the raw material used and partly a reflection of the particular warm climate that prevails in Algeria.

However, the in-house microflora investigated in this study was almost restricted to a single lineage with a persistence phenomenon across 4 years. This suggests a strong adaptation pattern of this lineage towards the ecological niche represented by the processing unit. Indeed, certain dairy plants are assumed to harbor particular plant-specific $B$. cereus which constantly contributes to post-pasteurization contamination (Schraft et al. 1999). Similarly, Salustiano et al. (2009) found that most of the $B$. cereus strains isolated from post-pasteurization equipment surfaces belonged to the same ribogroup. Once it is recovered from post-pasteurization segments, temperature appears to be the major factor that selects and maintains genotype A which best 
survives the various thermal stresses undergone in the unit and before that. Finally, phylogenetic classification previously revealed a genetic structure of $B$. cereus strains corresponding to groups with different abilities to adapt to temperature. Thus, $B$. cereus group III contains mesophilic strains characterized with a comparatively high heat resistance of their spores (in Carlin et al. (2010)).

Protection of strains within biofilms formed inside pipe milking system may also be a survival strategy for the selected genotype. This phenomenon is well known in the dairy industry (Tauveron et al. 2006; Wijman et al. 2007; Salustiano et al. 2009; Schlegelova et al. 2010; Shaheen et al. 2010), where the predominant type that could be detected is best capable of contaminating the milk processing system. This is particularly true for $B$. cereus strains which have frequently been described as efficient biofilm formers. Furthermore, spores of $B$. thuringiensis and not only $B$. cereus sensu stricto were recently found to have high potential to adhere to inert surfaces (Ankolekar and Labbé 2010; Auger et al. 2009).

In conclusion, the common origin associated to both the selective pressure of temperature and persistence into biofilms should be responsible for this plant-specific distribution of group III B. cereus specific genotype.

A particular interest of the genetic groups III and IV is that they contain strains which carry various genes encoding toxins, representing a high risk for food poisoning (Guinebretière et al. 2010). The enterotoxigenic genes, hbl, cytK-2, and nhe, are present in strains of the two genetic groups, while the emetic gene ces is present in some members of the phylogenetic group III. As previously reported (Svensson et al. 2006), milk powder represents an important source of emetic bacteria. Overall, the occurrence of both pathogenic and non-pathogenic B. cereus strains in the dairy environment is well-established. Numerous studies have shown that this organism originates from the raw milk and contaminates the process equipment and may contaminate the processed products. Such dairy products, notably pasteurized milk products, should be low at-risk or high at-risk foods depending on the toxins production potential of contaminating strains. This illustrates the need for techniques that rapidly and accurately provide discriminative and informative data for the foodpoisoning risk associated with $B$. cereus strains, as expressed in several reports (Thorensen et al. 2010; Chaves et al. 2011; Oh et al. 2012). Associating the phylogenetic groups with the different virulence potentials of $B$. cereus strains, first observed in Guinebretière et al. (2010), meets this requirement.

Algerian pasteurized milk is consumed by a large segment of the population including infants of less than 2 years. With regard to the food poisoning potential of identified strains, it may represent a health risk for consumers. However, to the best of our knowledge, no episodes of food poisoning have been reported after the consumption of pasteurized milk in Algeria. The reason for this may be the fact that the product is boiled by consumers before consumption. Unfortunately, this additional heating compromises once again the nutritional attributes of the product previously submitted to several heat treatments. Processors have then to particularly be aware that high temperature not only negatively affects the nutritional value of pasteurized milk but may also result in increasing $B$. cereus count in this product as shown by several studies (Hanson et al. 2005; Aires et al. 2009; Ranieri et al. 2009). Moreover, more attention must be paid to the quality and safety of Algerian pasteurized milk as an infant food, taking into account the particularities of this group of consumers. 
To our knowledge, this is the first report on molecular typing and phylogenetic affiliation of $B$. cereus strains isolated in Algeria. It is also the first practical application of this classification to the study of an individual plant. M13-PCR analysis successfully traced the spread of $B$. cereus strains in the dairy plant, indicating that contamination of pasteurized milk could be traced also to milk powder, and not as previously expected, only to the process equipment. The two molecular methods revealed the persistence of specific and potentially toxinproducing $B$. cereus genotypes. The toxigenic profiles of the corresponding strains have to be further determined in order to accurately assess pasteurized milk safety.

Acknowledgments The authors wish to express their gratitude to Dr. C. Nguyen-The for kindly playing host to Fadila Malek at UMR 408, INRA, Avignon France and to Dr. M.H. Guinebretière for coaching her on the molecular analysis and for critical reading of the manuscript.

\section{References}

Aires GS, Walter EH, Junqueira VC, Roig SM, Faria JA (2009) Bacillus cereus in refrigerated milk submitted to different heat treatments. J Food Prot 72:1301-1305

Ankolekar C, Labbé RG (2010) Physical characteristic of spores of food-associated isolates of the B. cereus group. Appl Environ Microbiol 76:982-984

Auger S, Ramaro N, Faille C, Fouillet A, Aymerich S, Gohar M (2009) Biofilm formation and cell surface properties among pathogenic and non pathogenic strains of the Bacillus cereus group. Appl Environ Microbiol 75:6618-6676

Bagge-Ravn D, Ng Y, Hjelm M, Christansen JN, Johansen C, Gram L (2003) The microbial ecology of processing equipment in different fish industries - analysis of the microflora during processing and following cleaning and disinfection. Int J Food Microbiol 87:239-250

Banykó J, Vyletelová M (2009) Determining the source of Bacillus cereus and Bacillus licheniformis isolated from raw milk, pasteurized milk and yoghurt. Lett Appl Microbiol 48:318-323

Barbano DM, Santos MV (2006) Influence of raw milk quality on fluid milk shelf-life. J Dairy Sci 89:15-29

Carlin F, Brillard J, Broussolle V, Clavel T, Duport C, Jobin M, Guinebretière MH, Auger S, Sorokine A, Nguyen-The C (2010) Adaptation of Bacillus cereus, an ubiquitous worldwide-distributed foodborne pathogen, to a changing environment. Food Res Int 43:1885-1894

Chaves JQ, Pires ES, Vivoni AM (2011) Genetic diversity, antimicrobial resistance and toxigenic profiles of $B$. cereus isolated from food in Brazil over three decades. Int J Food Microbiol 147:12-16

De Jonghe V, Coorects A, De Block J, Van Coillie E, Grijspeerdt K, Herman L, De Vos P, Heyndrickx M (2010) Toxigenic and spoilage potential of aerobic spore-formers isolated from raw milk. Int J Food Microbiol 136:318-325

Didelot X, Barker M, Falush D, Priest FG (2009) Evolution of pathogenicity in the Bacillus cereus group. Syst Appl Microbiol 32:81-90

Ehling-schulz M, Svensson B, Guinebretière MH, Lindback T, Anderson M, Schulz A, Fricker M, Christiansson A, Granum PE, Martlbauer E, Nguyen-The C, Salinkoja-Salonen M, Scherer S (2005) Emetic toxin formation of Bacillus cereus is restricted to a single evolutionary lineage of closely related strains. Microbiology 15:183-197

Eneroth A, Svensson B, Moli G, Christiansson A (2001) Contamination of pasteurized milk by Bacillus cereus in the filling machine. J Dairy Res 68:189-196

Guinebretière MH, Nguyen-The C (2003) Sources of Bacillus cereus contamination in a pasteurized zucchini purée processing line, differentiated by two PCR-based methods. FEMS Microbiol Ecol 43:207-215

Guinebretière MH, Thompson FL, Sorokin A, Normand P, Dawyndt P, Ehling-schulz M, Svensson B, Sanchis V, Nguyen-The C, Heyndrickx M, De Vos P (2008) Ecological diversification in the Bacillus cereus group. Environ Microbiol 10:851-865

Guinebretière MH, Velge P, Couvert O, Carlin F, Debuyser ML, Nguyen-The C (2010) Ability of Bacillus cereus group strains to cause food poisoning varies according to phylogenetic affiliation (groups I to VII) rather than species affiliation. J Clin Microb 48:3388-3391 
Hanson ML, Wendorff WL, Houk KB (2005) Effect of heat treatment of milk on activation of Bacillus spores. J Food Protec 68:1484-1486

Huck JR, Hammond BH, Murphy SC, Woodcock NH, Boor KJ (2007) Tracking spore-forming bacterial contaminants in fluid milk-processing systems. J Dairy Sci 90:4872-4883

Lin S, Schraft H, Odumeru JA, Griffiths MW (1998) Identification of contamination sources of Bacillus cereus in pasteurized milk. Int J Food Microbiol 43:159-171

Moussa Boudjemaa B, Kihal M, Lopez M, Gonzalez J (2004) The incidence of Bacillus cereus spores in Algerian milk: a study on the chief sources of contamination. Archive fur leben smittelhygiene 55:73-76

Oh MH, Ham JS, Jm C (2012) Diversity and toxigenicity among members of the B. cereus group. Int J Food Microbiol 152:1-8

Ranieri ML, Huck JR, Sonnen M, Barbano DM, Boor KJ (2009) High temperature, short time pasteurization temperatures inversely affect bacterial numbers during refrigerated storage of pasteurized milk. $\mathrm{J}$ Dairy Sci 92:4823-32

Salustiano JC, Andrade NJ, Soares NFF, Lima JC, Bernardes PC, Luiz LMP, Fernandes PE (2009) Contamination of milk with $B$. cereus by post-pasteurization surface exposure as evaluated by automated ribotyping. Food Control 20:439-442

Schlegelova J, Babak V, Holasova M, Konstantinova L, Necidova L, Sisak F, Vlkova H, Roubal P, Jaglik Z (2010) Microbial contamination after sanitation of food contact surfaces in dairy and meat processing plants. Czek J Food Sci 28:450-461

Schraft H, Steele M, McNab B, Odumeru J, Griffiths MW (1999) Epidemiological typing of Bacillus spp. isolated from food. Appl Environ Microbiol 62:4229-4232

Shaheen R, Svensson B, Andersson MA, Christiansson A, Salkinjova-Salonen M (2010) Persistence strategies of Bacillus cereus spores isolated from dairy silo tanks. Food Microbiol 27:347-355

Sharma M, Anand SK (2002) Characterization of constitutive microflora of biofilms in dairy processing lines. Food Microbiol 19:627-636

Svensson B, Eneroth A, Brendehaug J, Christiansson A (1999) Investigation of Bacillus cereus contamination sites in a dairy plant with RAPD-PCR. Int Dairy J 9:903-912

Svensson B, Eneroth A, Brendehaug J, Molin G, Christiansson A (2000) Involvement of a pasteurizer in the contamination of milk by Bacillus cereus in a commercial dairy plant. J Dairy Res 67:455-460

Svensson B, Ekelund K, Ogura H, Christiansson A (2004) Characterization of Bacillus cereus isolated from milk silo tanks at eight different dairy plants. Int Dairy J 14:17-27

Svensson B, Monthan A, Shaheen R, Andersson MA, Salkinojova-Salonen M, Christiansson A (2006) Occurrence of emetic toxin producing Bacillus cereus in the dairy production chain. Int Dairy $\mathrm{J}$ 16:740-749

Svensson B, Monthan A, Gunibretière MH, Nguyen-The C, Christiansson A (2007) Toxin production potential and the detection of toxin genes among strains of the Bacillus cereus group isolated along the production chain. Int Dairy J 17:1201-1208

Tauveron G, Slomianny C, Henry C, Faille C (2006) Variability among Bacillus cereus strains in spore surface properties and influence on their ability to contaminate food surface equipment. Int $\mathrm{J}$ Food Microbiol 110:254-262

Te Giffel M, Beumer RR, Langeveld LPM, Rombouts FM (1997) The role of heat exchangers in the contamination of milk with B. cereus in dairy processing plants. Int J Dairy Technol 50:43-47

Thorensen 1, Azokpota P, Hansen BM, Hounhouigan DJ, Jakobsen M (2010) Identification, genetic diversity and cereulide producing ability of Bacillus cereus group strains isolated from Beninse traditional fermented food condiments. Int J Food Microbiol 142:247-250

Wijman JGE, de Leeuw PPLA, Moezelaar R, Zwietering MH, Abee T (2007) Air liquid interface biofilms of Bacillus cereus: formation, sporulation and dispersion. Appl Environ Microbiol 73:1481-1488 